\title{
Post-Communist Transition and Common Ground: A Mongolian Perspective
}

\author{
By D.Bayarkhuu (Mongolia)
}

\section{New Dimension and Definition}

The five categories of actors in the world politics, as described Prof. Hans Binnendijk, from the US National Defense University, is being shaped by at least four dominant trends, with each trend affecting the actors in different ways. This accounts for much of the complexity apparent in the new Post-Cold War system.

The most dominant actors are the market democracies. Their ideology has become the global model, and at the end of the decade more than half of the world's nations can be characterized as democracies. States in transition constitute second group that are hopefully moving toward market democracies. The most important of these transition states are China, Russia, and India. Their ultimate orientation may be the most decisive determinant of how the more mature system will look. The third category of actors consists of the so-called rogue, or rejectionist states: notably Iraq, Iran, North Korea, Libya, the Sudan, Afghanistan, Cuba, and then Serbia. A fourth category of actors consists of the failing states: Bosnia, the Democratic Republic of Congo, Cambodia, Algeria, Somalia, Tajikistan, and Haiti, to name just a few.

Finally, non-state actors have begun to take on many state characteristics. Some, such as global companies, support the market democracies; some, like international crime syndicates, prey on them; and some, for example terrorist organizations, seek to bring the market democracies down. The last two might be called the transnational outlaws. Four worldwide trends have had both positive and negative effects on these five categories of actors. The effect of the trends is to pull some actors together and push others apart. ${ }^{1}$

The rapid globalization of events the first trend is based on new information technology and has increased the pace of events in economics, politics, military affairs, and communications. Economic globalization has brought unprecedented wealth to most market democracies (the Asian downturn notwithstanding). Moreover, it attracts the transition states and it can empower

${ }^{1}$ Hans Binnendijk. Back to Bipolarity ? The Washington Quarterly, Autumn 1999, pp. 10-11 
the transnational outlaws. But rogue states tend to reject the political, cultural, and some economic aspects of globalization, while the failing states are not reaping its benefits at all and are falling further behind.

Democratization-the second trend -has had a similar effect. It can provide for peaceful transfers of power and attracts transition states such as India, and Russia. But it has deepened fissures within many failing states as ethnic, tribal, or religious groups simply vote with their group.

Fragmentation-the third trend-has ironically been stimulated by globalization as groups seek to differentiate themselves in a homogenizing world and to maximize power at the local level. This devolution of power is a phenomenon found nearly everywhere in the world today, but it has a very different impact on different actors. In market democracies, it has led to generally positive outcomes such as greater power sharing with state governments in the United States and the concept of "subsidiary" (decisions made at lowest possible level) in the European Union. In the most important transition states (e.g., Russia, China, and India), however, fragmentation has led to armed conflict (i.e., Chechnya, Xinjiang, and Kashmir). These conflicts have in turn led to additional political problems between these transition states and the market democracies. Fragmentation along ethnic lines is now the leading cause of state failure. It provides new opportunities for transnational criminal and terrorist organizations.

Preventing and countering a fourth trend, the proliferation of weapons of mass destruction, has been a national priority for the United States throughout the early years of new international system. Many of the other market democracies are only now awakening to its serious dangers. Proliferation gives rogue states and even some nongovernmental groups the potential to threaten and possibly undermine U.S. policies. It is no surprise that this issue has dominated U.S. relations with North Korea and Iraq. The impact of proliferation on the large transition states has been mixed, because China and Russia both supply technology and are threatened by it. Given the evidently polarizing effect of these four worldwide trends, one must ask whether the life cycle of the sixth international system is also moving in the direction of eventual bipolarity. A look at recent relations among the major powers indicates that this is a real possibility. ${ }^{2}$

${ }^{2}$ Ibid. 


\section{The Transition}

We live in an era of increasing democratization and globalization. Today issues related to democracy have a global dimension that cannot and must not be ignored. The world, at the crossroads of the present two centuries, looks more prospective, brighter, and more hope-inducing cradle of humankind after the two world wars, colonial collapse, fascism, and communism.

Even though democracy in a society is a relatively recent phenomenon compared to the history of humankind and civilization, yet it has historically proven its legitimacy and advantages with concomitant results whereby a great deal of countries and nations have made a transition to this system in the past 10-20 years. These, first of all, include the underdeveloped countries of Africa, the Latin American countries under the control of the military, Asian countries that suffered immense reparations for many years, and the Post-Communist Asian and European countries.

The collapse of the Soviet Union and the world communist system in the 1990s served as a catalyst for a democracy to become a truly global phenomenon. As of now, there are over 50 post-communist countries worldwide, which are making a transition from a politically oppressive regime to a democratic state establishment. $^{3}$

Looking at the countries that are currently making democratic reforms one can conclude that, by general statistics, they are making a peaceful and stable transition, however, if taken under a case-by-case scrutiny, the level of success for each country varies. In this case, the success factor, above all, depends upon the human factors, the people's education level of the country concerned, their mentality, and their preparedness to embrace democratic values. The next deciding factor determining a success is the economic capacity and level of development of these countries.

Enormous advances in science and technology, as well as the formation of a pleasant climate settled in after the Cold War, and the worldwide processes of integration and globalization are attributable to the principal structural changes in the present world economy. States are losing some of their authority to emerging new transnational powers- multinational corporations, global media groups, and today's dynamic and mobile financial capitalism, which is exempt from any international control and only weakly linked to individual nations. This requires a rethinking of the nature, powers, and resources of international

${ }^{3}$ According to the UN Report, 36 countries started the post-cold war transition 
organizations (like the UN and its specialized agencies) and of regional organizations (like the EU), with a view to rendering them more democratic. ${ }^{4}$

At this time, when the world is going for a single market, attempts to stay aloof from this tendency are fraught with immense costs and create a paradoxical situation. That is why the formation of an economy similar by the basic principles, basic structures and mechanisms by countries reveals the dual, concurrent nature of the present transitions. With the exception of few countries like North Korea, this global transition of economy has involved every country of the world. Still, being subject to different starting conditions, order of technological advancement, and human factors, the results of the transition are varying from one country to another.

\section{A Model, Categories and Stages of the Transition to Post-Communism}

As related to the above, let us first consider the structural changes taking place in some of the democratic and rich countries of the West ${ }^{5}$, wherein socialist elements have been commonplace for many years.

Eurasian and Latin American countries are making a second-level transition. In order to attain a higher technological order, these countries are emphasizing an employment of the most-accelerated mechanisms, while at the same time, putting the society's democratization on the second place. Only after reaching a certain level and stage, they would undertake social reforms.

Third-level of economic reforms are taking place in the Asian PostCommunist and communist countries and as one can see the transitions they are making are painful and difficult. ${ }^{6}$

The reason being is that common market relations were long abandoned and the so-called centrally - planned economy, a completely new one to the humankind's entire history, was governing in these countries. By contrast, all the properties were practically under a 100-percent state-ownership in such countries as Mongolia, North Korea, Laos and Cambodia. The level of development of these countries was different when they embarked on the path to communism. These transitions involve the following basic types.

With regard to the prospects of all of these countries, they can be grouped into four categories: ${ }^{7}$

${ }^{4}$ Mario Soares. The Democratic Invention, Journal of Democracy, April 1999, pp 111

${ }^{5}$ Samuel P. Huntington notes that there were, by his count, 58 democratic countries in 1990. Of those, he points out, 37 were West European, European-settled, 6 were East European, and 9 were former colonies of the UK (The Third Wave: Democratization in the Late Twentieth Century, Norman: University of Oklahoma Press, 1991, pp. 299) Challenges and Opportunities, The Asia Foundation, Ulaanbaatar, Mongolia, 2001(Conference collection book) pp. 12

${ }^{6}$ Baabar B.Batbayar. Concurrent Transition. Mongolia's Political and Economic Transition: Challenges and Opportunities, The Asia Foundation, Ulaanbaatar, Mongolia, 2001 (Conference book)

${ }^{7}$ Ibid. pp. 13 
Some of them will succeed in both political and economic reforms.

Others, including Mongolia, will experience successful political reforms but their economic transformation will be slow.

A third category of countries will experience the reverse, with booming economies but human rights abuses and little, if any, real democratic reforms.

Finally, a few unfortunate countries will continue to have neither political nor economic reforms.

Economy-based transition: China and Vietnam are among the countries, which are implementing this type of transition with considerable success. These countries are seeking to gradually withdraw from the communist ideology, and to get rid of the ideological straps and buckles by peaceful means. Their main focus is on the liberalization of economy. China and Vietnam have shifted to a hybrid form, which introduced free-market economies while allowing the Communist party to retain authoritarian control over state and society. The results so far in both countries have shown rapid economic growth.

Economic and political transition: Central Asian countries, particularly, Turkmenistan, Uzbekistan, and at varying degree, Kazakhstan and Kyrgyz Republic are, apart from undertaking deep economic reforms and liberalization, trying to emulate the "tiger's path" of the Southeast Asian countries through conduct of social reforms by way of replacing a former order or substituting one dictatorship by another.

Political and economic transition: Most East European countries, on the basis of the firm democratic reforms pertinent to society, are carrying out economic reforms through the mechanisms of constitutional polity. In this regard, Mongolia has chosen this difficult yet prospective type of transition.

Political transition: Countries that have the objective to make a political and economic transition as stated above but their principal political transition has not been successful as yet, and where domestic disputes do not take place within the legal framework are included in this category. It encompasses Russia, and in some aspects the Caucasian countries, which are infused with conflicts between domestic subjects and where the Constitutional crisis is present.

Since the dissolution of the Soviet Union, the political development in the Post-Communist World can be divided into five categories.

The remainder of the Communist system.

The disintegration of the Nation.

The integration with the Capitalist State.

The transformation with instability.

The reformation with stability. ${ }^{8}$

${ }^{8}$ Ten-Kuang Chang. Mongolia: A Country Profile (Special report 1993) 
Many examples of transition have considered, it is possible to highlight commonalities. Earlier, a simple three-type model and five-categories of the transition was suggested, primarily as a method for identifying when a particular country had reached democracy and free market economy.

As with all models, this one has its limitations; not all countries experienced all stages of transition, and the sequence varied somewhat from case to case. Comparative analysis suggests at least the following eight discernible stages in the transition from communist power to post-communism:

Leadership crisis.

Round Table talks

The party loses its leading role.

Legalization of opposition parties.

Significant changes to the communist party.

Holding of competitive parliamentary elections.

The name of the state is changed.

Adoption of a new highly modified constitution. ${ }^{9}$

In case of Mongolian transition lesson, can be analyze at least the following four stages, such:

To agree on the ideas of Democracy

To end communist bureaucratic control

To start market oriented economy

To held Pluralistic elections and, the democratic, peaceful handover of power.

The ways in which and reasons why the former Soviet and East European states, as well as Mongolia overview communist power moved to postcommunism have now been analyzed, as have some of the reasons why a few communist states survive.

It is also argued here that the few remaining communist states is the problematic nature, will not be so far much longer. The reasons will give in the case of China and North Korea, as well as further points can find these in later on.

Indeed, since the early 1980s, Chinese Communist Party has been transforming itself from a mass-revolutionary formation into a pragmatic party willing to make social and political reforms in order to maintain the system under girding its rule and to meet the challenges of economic modernization. Initiated by the communist party, political liberalization occurred mainly in three broad areas:

${ }^{9}$ Leclie Holmes. Post-communism: An Introduction, Polity Press, 1997, pp. 127-130 
Reconciliation between state and society, accomplished mostly trough the communist party's reduction of the scope and arbitrariness of political interventions in daily life and ordinary citizens began to enjoy much greater freedom of belief, expression, and consumption than they had under Mao.

Expanded opportunities for popular participation in political affairs at both the grassroots and national levels. The introduction of competitive elections to local legislature, the expansion of the role of the National People's Congress and growing consultation with various social groups through several institutional mechanisms have characterized the post-Mao reforms.

Redefinition of the content and role of the official ideology in such a way as to create a new basis for political authority. Instead, the main task of politics came to be seen as promoting modernization and reform. ${ }^{10}$

There is no single model of democratic development- or democratic nondevelopment, for that matter - in the Asian region. Some countries (most notably the Philippines) have a long but troubled historical experience with democracy. Some (Japan and India) underwent an abortive democratic transition in the interwar period and has had a successful history of democracy since the end of the Second World War. Singapore, according to all indicators of economic and social development, should have a democracy but does not. South Korea, Taiwan, Mongolia, and Cambodia seem to be moving toward the institutionalization of democratic forms of governance. In case of the Central Asian newly independent countries, and some countries Southeast Asia, the democratization is critical question and still too early say definitively whether democratic consolidation will actually occur or what kind of democracy will evolve in either place. These countries are in the early stages of democratic transition - is whether positive economic performance can be sustained long enough after the introduction of democracy to build a solid and broad base of support for newly introduced democratic institutions.

Despite the diverse historical experiences and current realities of East Asian countries that have democratized or are democratizing, offers six key lessons that should be heeded by anyone concerned about democratic political development.

The first of these lessons is that in establishing and consolidating democracy, leadership matters a great deal.

The second lesson about democratic development is that institutional matter. pp. 55

${ }^{10}$ Suisheng Zhao. Will China Democratize? Three Scenario, Journal of Democracy, January 1998, 
A third lesson to be derived concerns the relationship between political and economic development. The empirical evidence from East Asia lends strong support to the view that democratization is facilitated, though not caused, by economic growth.

The fourth lesson can be drawn, as importance to democratizationinvolving leadership, institutions, and economic development- is hardly unique to East Asia.

The fifth lesson of experience is that the international context matters, and not just in the sense of direct foreign influences. The pursuit of exportoriented growth policies has made countries emphasize mass education, the training of the labor force, and the obtaining and processing of vast quantities of information.

The sixth and final lesson to be drawn from experience with democracy has to do with what it is not about. And what it is not about is culture. The history of democratization in East Asia is one of variation and diversity- and not only across national boundaries, but also within countries. ${ }^{11}$

\section{Mongolia's Concurrent Transitions}

With the collapse of communism, all countries under that system were immediately affected, but in divergent ways. Mongolia and Eastern European countries gained genuine political independence from Moscow. Mongolia completely abandoned the Communist system of government. Mongolia is in the category of reformation with stability based on peaceful evolution.

Mongolia's democratic status is reflected in cross-national studies. The Mongolian experience holds lessons for scholars, analysts, and policy makers.

First, it demonstrates the supreme value of a commitment to compromise. Avoiding political violence, always and everywhere democracy's most venomous antagonist left the door open to early, broad strides toward democracy even under inhospitable circumstances.

Second, Mongolia showcases the virtues of institutions that disperse power, and particularly of a legislature-dominant from of semipresidentialism.

Third, the Mongolian experience highlights the advantages of the absence of a single "father" of democracy and national independence. In most post communist counties that do or did have such personages, such as Russia, Croatia, Albania, Kazakhstan, the Kyrgyz Republic, and Armenia, such figures were widely regarded as valuable assets early in the transition.

${ }^{11}$ Gerald L.Curtis. A "Recipe" for Democratic Development, Journal of Democracy, January 1997, 
Fourth, Mongolia' transition demonstrates the enormous potential of political parties to advance democratization.

Fifth, the case under examination evinces the independent power of a strong civil society. ${ }^{12}$

Only the Czech Republic, Hungary, Poland, Slovenia, and the three Baltic states scored higher than Mongolia, which was the only post communist country outside of Eastern Europe to be ranked "free." Roughly half the countries of Eastern Europe as well as all of those of the former Soviet Union expect the Baltic States were rated "partly free" or "not free." Mongolia also scored high in terms of press freedoms. It ranked ninth in the post-communist world, just three points (on a 100-point scale) behind Hungary. ${ }^{13}$

Table - Freedom Status of Post communist Countries

\begin{tabular}{lll} 
Free & Partly Free & Nor Free \\
Czech Republic & Slovakia & Azerbaijan \\
Estonia & Macedonia & Kazakhstan \\
Hungary & Moldova & Belarus \\
Lithuania & Russia & Yugoslavia (Serbia and \\
Poland & Ukraine & \multicolumn{1}{c}{ Montenegro) } \\
Slovenia & Albania & Tajikistan \\
Latvia & Croatia & Turkmenistan \\
Bulgaria & Georgia & Uzbekistan \\
Mongolia & Kyrgyz Republic & \\
Romania & Armenia & \\
& Bosnia-Herzegovina &
\end{tabular}

Two dimensions of freedom-political rights and civil liberties- are measured on a seven-point scale, with a rating of one indicating the most free and seven the least free. In this scenario, China, North Korea, Vietnam, Laos, and Cuba each received a combined average rating of seven.

In the past Mongolia had always followed any change and reform in the Soviet Union, but the Mongolian version of perestroika was started much later than the Soviet Union, i.e. in 1988, and proceeded much slower. Facing

\footnotetext{
${ }^{12}$ M. Steven Fish. Mongolia: Democracy without Prerequisites,

Journal of Democracy, July 1998, pp. 139-140

${ }^{13}$ Freedom in the World: The annual Survey of Political Rights and Civil Liberties 1996-1997, New York, Freedom House, 1997, Press Freedom World Wide, 1997: Tables and Ratings

${ }^{14}$ Source: Data from Freedom House, Journal of Democracy, July 1997, pp. 94
} 
unprecedented shock in the modern history of the world Mongolia managed to recover relatively quickly. ${ }^{15}$

Until the 1990s, Mongolia had no tradition of democracy. Mongolian democracy, in light of most social-science theories and commonsense expectations, should have never been. Geography afforded Mongolia no advantages. It is one of the world's most isolated countries, far from the Western influence that many observers regard as crucial to democratization in post communist Eastern Europe. Mongolia experienced greater initial political continuity at the onset of its post-Soviet transition than did many other post communist countries. ${ }^{16}$

After victory of the 1921 people's revolution, the country followed the road of communism for 70 years. Mongolia is the second oldest Communist State in the world, but is the first state in Asia that has transformed from Communism to democracy based on a constitutional approach. Since the advent of democracy in 1990s, Mongolia conducted democratic election and became parliamentary state. Thus Mongolia has made a peaceful transition to stable democracy. Mongolia, along with making a transition from the totalitarian regime to a political and social democracy for the past ten years, is a country that has dismantled the old centrally-planned economy under which everything was state-owned and has now embarked on the path to market relations.

It is due to this and to the fact that unpleasant start-up conditions and various external and internal factors have made Mongolia's concurrent transition a most tough one. It is not because Mongolia chose this particularly difficult type of transition on purpose, but rather, there was no other choice left for her. Mongolia can be peacefully transformed from Communism to democracy because of its special character of geographic, historic, and cultural background, its adoption of democratization, and its adaptation to the new international environment. ${ }^{17}$

Taking into account the Mongols' peculiarity, level of education, and character, as well as the relations with the outside world and issues concerning Mongolia's national security, one can assume safely that it was impossible for the country to follow the economic reforms with no change in ideology as China, or that of Kazakhstan's whereby one regime was replaced by another, while at the same, economic reforms were undertaken at a vigorous pace. Aside

\footnotetext{
${ }^{15}$ R. Amarjargal. Mongolia: The early stage of transition, Lecture in JIIA, Tokyo, 26.11.2002

${ }^{16}$ M. Steven Fish. Mongolia: Democracy without Prerequisites,

${ }^{17}$ Ten-Kuang Chang. Mongolia: A Country Profile (Special report 1993)
} 
from these, Mongolia's starting level and assets were peculiarly worse and far from the standard of other communist countries, which altogether made it imperative that it undertakes a complete and comprehensive reform. ${ }^{18}$

Mongolia was a country with its state budget composed largely of foreign investment (its share was as high as $70 \%$ ) usually being made as a favor for showing ideological solidarity, with the lowest GDP per capita in the communist world, and with the biggest foreign debt in the world if compared to its population. Private properties were never permitted; in fact, law, which placed Mongolia in a very unique position in the communist world, strictly restricted private ownership.

Although political, economic, and social reforms face a number of risks, the positive aspects are rather dominant and overall frame or direction of the reform process is right. However, such negative phenomena as unemployment and poverty have become rather common and, given the lack of knowledge and expertise in dealing with these problems, the country was not able to prevent let alone limit the negative consequences the problems. ${ }^{19}$ Generally, in the coming decade of the new century, in terms of political reforms, Mongolia is an independent democratic nation aiming to further advance its parliamentary governance, in terms of the economy its is projected that the country's economy will completely transform into an market-oriented system, and in terms of social policy, it is projected that substantial changes will take place in the social sector, including the guaranteed freedom of people. ${ }^{20}$

Legal acts governing the regulation of economy were almost non-existent and all its regulatory matters were handled by few people and at the discretion of the nomenclature. Since all the properties were state-owned, there was present no idea of management whatsoever and no wonder that the co efficiency of capital utilization was remarkably low. Trades with hard currency that constituted a one-two percent of the GDP were not conducted in accordance with the applicable international rules and norms. In a word, Mongolia was an isolated and surrealist world on its own.

Mongolia is the second oldest Communist State in the world, but is the first state in Asia that has gradually transferred from Communist rule to the liberation of communism and, from Communism to democracy based on a

${ }^{18}$ Baabar B.Batbayar. Concurrent Transition. Mongolia's Political and Economic Transition: Challenges and Opportunities, The Asia Foundation, Ulaanbaatar, Mongolia, 2001 (Conference collection book) pp. 15

${ }^{19}$ P.Ochirbat, Former President of Mongolia. Dinner Address, Ibid, pp. 33

${ }^{20}$ N.Enkhbayar. PM of Mongolia. Luncheon Speech, Ibid, pp. 23 
constitutional approach, and finally to a total abandonment of communism. Events abroad and at home at that time brought a major rethinking of Mongolia's domestic and foreign policy. That was a great challenge for Mongolia. Opting for democracy and market-oriented economy Mongolia could expand relations with a greater number of nations. Since the advent of democracy in 1990s, the world's developed Western countries and international organizations supporting Mongolia's transition to democracy and market economy have rendered it technical and financial aid, granted loans.

Western assistance was aimed at facilitating Mongolia's transition from colonial status in the Soviet empire to a market economy based on Mongolia's natural wealth. Mongolia is determining to convince the West and the international donor community that it would keep economic and political reforms in country on track. ${ }^{21}$

${ }^{21}$ Christopher M. Finch. Mongolia in 2001, Asian Survey, January-February 2002, pp. 45 